NASA Technical Memorandum 103237

\title{
NASA Aerospace Flight \\ Battery Systems Program
}

Michelle A. Manzo and Patricia M. O'Donnell

Lewis Research Center

Cleveland, Ohio

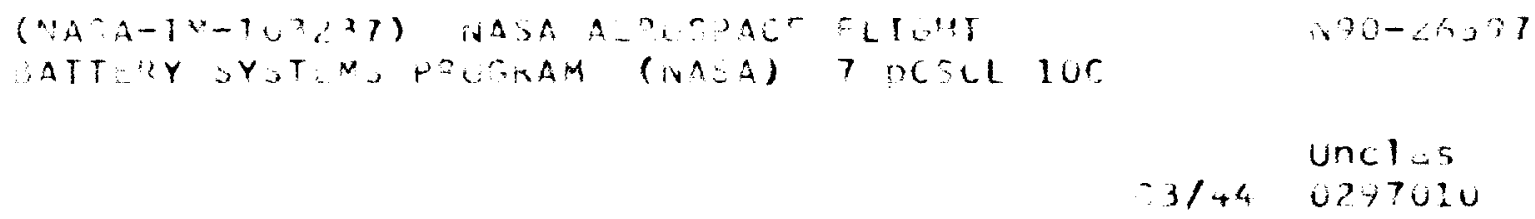

Prepared for the

25th Intersociety Energy Conversion Engineering Conference cosponsored by the AIChE, ANS, SAE, ACS, AIAA, ASME, and IEEE Reno, Nevada, August 12-17, 1990

\section{Mns/}


$+$ 


\title{
NASA AEROSPACE FLIGHT BATTERY SYSTEMS PROGRAM
}

\author{
Michelle A. Manzo \\ Patricia M. O'Donnell \\ NASA Lewis Research Center \\ Cleveland, Ohio 44135
}

\begin{abstract}
The major objective of the NASA Aerospace Flight Battery Systems Program is to provide NASA with the policy and posture to increase and ensure the safety, polic and pance and reliability of batteries for space pystems. The program plan has been modified in the past year to reflect changes in the agency's approach to battery related problems that are affecting flight programs. Primary attention in the Battery Program is being devoted to the development of an advanced nickel-cadmium cell design and the qualification of vendors to produce cells for flight programs. As part of a unified Battery Program, the development of a nickel-hydrogen standard and primary cell issues are also being pursued to provide high performance NASA Standards and space qualified state-of-the-art primary Standards and space qualised is being addressed with cells. The resolution participation of the aerospace battery community.
\end{abstract}

\section{INTRODUCTION}

The NASA Aerospace Flight Battery Systems Program The NASA Aerospace NASA wide effort with the reprective of providing NASA with the policy and posture which will increase the safety, performance, and reliability of space power systems. The program reliability of space power systems. accomplish this objective. These are: Battery Systems accomplish this objective. Battery Technology, and Primary Battery Technology. The approach to Primary Battery Technology. The abjectives involves 1) increasing the fundamental understanding of primary and the fundamentary cells; 2) providing for improved nickelcadmium manufacturing process control; 3) providing for the establishment of a NASA standard nickel-hydrogen cell design; 4) establishing specifications, design and operational guidelines for both primary and secondary operational guldels 5) providing training relating to the above areas; and 6) opening and maintaining communication lines within NASA and the aerospace community.

The NASA Lewis Research Center (LeRC) has the overall responsibility for management of the program. overall responsibility for management Research Center is the program manager. The majority of the NASA is the program manager. within the program. The overall objectives, guidelines within the program. through Code $Q$, the Office of Safety, Reliability, Maintainability and Quality Assurance. In January of Mrank Manning was named as the Headquarters, Code $Q$ program manager. The NASA Hatery Steering Committee provides advice on battery issues. The Committee is chaired by the Office of issues. The Committee is chaired by the Oaintainability and Quality
Assurance membership is comprised of one representative from each of the NASA centers and one representative from Aerospace Corporation, representing representative from Aerospace Corporation, of the tasks in the program plan, the initiation of the plan and in the program plan, have been previously reported in references 1 through 4 .

The major change in the program over the past year involves the approach to the resolution of the situation that has developed with regard to the quality and reliability of nickel-cadmium secondary cells. The original approach involved the establishment of a semidedicated line as a means of producing reliable, high dedicated line as a means of producing aerospace nickelcadmium cells. The semi-dedicated line has been cadmium cells. The semi-dedicated the development and implementation of rigid specifications detailing production and quality rigid specifcations for the cells. This has resulted in control requirements for the NASA Aerospace Battery Systems Program Plan to address the issues at hand. The overall plan, the specific modifications, and the status of the tasks will be addressed in this paper.

\section{PROGRAM PLAN OVERVIEW - TASK STATUS}

This program is designed to enhance the safety, reliability, and performance of NASA's aerospace reliability, and performance of as well as battery power systems. The program is organized under four power systems. Program Management, Battery Systems Technology, Secondary Battery Technology, and Primary Battery Technology.

\section{Program Management}

The NASA Lewis Research Center is responsible for the management of this program. The NASA Lewis Research Center Program Manager provides continuing coordination with all the NASA centers, Jet Propulsion caoboratory (JPL), NASA Headquarters and the Battery Steering Cornmittee. The Lewis Research Center Program Manager has full responsibility for technical management, cost and scheduling of the program.

\section{Battery Systems Technology}

The Battery Systems Technology Task addresses the The Battery aspects associated with the integration of cells into batteries and batteries into power systems. The objective is to improve the reliability of energy storage space power system design, integration, and checkout.

The Goddard Space Flight Center (GSFC) is developing a NASA Battery Systems Handbook that will define 
good, consistent design, integration and checkout practices to be applied across all NASA programs. Secondary nickel-cadmium and nickel-hydrogen oystems will be emphasized. Mr. Jim Dunlop has been hired as a consultant to aid in the development of the handbook. A preliminary draft of the handbook has been produced and is presently under review. The Battery Systems Handbook will address the following subjects: 1) Salient Characteristics of Battery Systems, 2) Battery Systems Design, 3) Battery Design, 4) Battery Manufacturing (Procurement), 5) Battery Acceptance Testing, 6) Battery Storage and Handling, and 7) Safety.

The handbook is intended to serve as the basis for a training program, that will ensure that personnel at both the engineer and technician levels, involved with the design, test, integration, and operation of batteries and their related power systems are fully trained and qualified for safe and proper operational procedures. The training program is also intended to foster advanced expertise in the battery area within the agency.

The Battery Data Base subtask addressed a NASA Battery System Environment to serve the NASA battery community for the dissemination of technical notes, policy documentation and test data. Efforts are underway to develop a battery specific data base that would provide access to operational cycle test data in addition to a problem reporting system. The battery data base will serve as an integrated repository of knowledge gained from manufacturing, ground testing, and flight experience. The goal is to permit all NASA centers to input and retrieve pertinent information, and to facilitate the issuance of rapid alerts when potential problems and/or trends have been identified. Data base capabilities in the following areas will be established: bulletin boards, a documentation library, test data archives, and battery models. Ames-Dryden Flight Research Facility has assumed responsibility for implementation of this subtask.

The bulletin board that will allow access to the Crane test data has been established. As part of this subtask, Crane has been asked to update NASA pack history files dating back to 1975 , provide pack record structure information and convert data tapes to a useable format for all NASA tests dating back to 1981. Crane has delivered tapes containing the pack history files on some of the NASA sponsored tests to $A$ DFRF. This initial data is presently accessible through the data base. A procedure for long-term support of the NASA data base is being established. Monthly transmittals will be made for data record tapes, pack history record updates, and pack structure changes.

The NASA Battery Workshop comes under the sponsorship of the NASA Aerospace Battery Systems Program. The workshop serves as a forum for open communication of battery related activities between industry and government. The next workshop will be sponeored by the Marshall Space Flight Center. It is scheduled to be held in November of 1990 . Future Workshops will be held in the spring of even numbered years, alternating with the NASA Lewis Space Electrochemical Research and Technology (SERT) Conference.

The future requirements and applications for both primary and secondary battery syatems are continuously monitored as part of Battery Systems Task. The Lewis
Research Center has responsibility for this subtask.

\section{Secondary Battery Technology}

The secondary Battery Technology Task was established to improve the performance, quality, safety, and reliability of secondary battery systems. This task presently focuses on the nickel-cadmium and nickelhydrogen systems which encompass the majority of NASA's present and planned secondary battery applications.

The resolution of the nickel-cadmium cell quality and reliability problems are the major concern of this task. Near-term and far-term options for the resolution of the life and reliability problems with the current design nickel-cadmium cells are being implemented as part of this task. The near-term approach is aimed at the reestablishment of a qualified Standard Nickel-Cadmium Cell. It involves the evaluation of SAFT cells and Hughes "advanced" Ni-Cd cells as possible replacements for the current NASA Standard cells produced by Gates Aerospace Batteries. A number of cells has been provided by SAFT for evaluation by NASA. 20 and 24 AH cells are currently on test. Tests have been in progress for greater than one year. Testing is being conducted at $40 \%$ DOD and 0 and $20^{\circ} \mathrm{C}$. The data sccumulated to date shows performance of the SAFT cells to be comparable to that of the NASA Standard cells used for LANDSAT. Sixty advanced design NiCd cells have been purchased from Hughes. Seven five to eight cell test packs of advanced design cells and an additional eight cell pack of 'super' Ni-Cd cells are currently undergoing stress testing at $40 \%$ DOD at Crane. The advanced design cells do not contain the electrolyte additive used in the 'super' $\mathrm{Ni}-\mathrm{Cd}$ cells. The Goddard Space Flight Center is responsible for the procurement and testing of the above cells.

Modifications to the present Gates cells are also being investigated as a part of the near-term solution. An interactive contract with Gates, under the management of the Lewis Research Center, has been initiated that would allow variations in the porosity, nickel attack level, and the loading level of the positive electrodes as well as the incorporation of modified separators, and varied electrolyte levels. Modified cells will be constructed and tested to evaluate the effectiveness of the component changes.

NASA, through the Goddard Space Flight Center, is also in the process of revising the NASA Specification for Manufacturing and Performance Requirements of NASA Standard Aerospace Nickel-Cadmium Cells, NHB 8073.1. The NHB was originally written to update the existing pecification to correlate with the current NASA Standard Nickel-Cadmium Cell Manufacturing Control Documents at Gates Aerospace Batteries. The NHB is presently being revised to do the following: 1) strengthen the technical contents and requirements of the document; 2) incorporate performance assurance requirements and thereby improve the quality of the cells produced; and 3) incorporate comments received from Gates Aerospace Batteries on the present version of NHB 8073.1.

The approach for the proposed long-term resolution of the nickel-cadmium situation has changed over the past year. The original plan was to establish a semidedicated line for the production of a NASA Standard Advanced Nickel-Cadmium Cell. The major goal of 
this subtask, the identification and development of an advanced nickel-cadmium cell design, has not changed. However, the semi-dedicated line spproach has been abandoned. The definition and development of a NASA standard advanced nickel-cadmium cell for NASA Secondary battery applications is to be accomplished by developing detailed, rigid specifications and sponsoring the development of manufacturing, testing and inspection processes by both government and contractor agencies. The present approach is to procure cells, from any qualified bidders, built to the rigid specifications required to ensure the quality and reliability of the cells. The cells will be tested and vendors qualified. The advanced design requires electrochemically impregnated plates and a separator capable of sustained operation at 30 degrees $C$. Goddard Space Flight Center has responsibility for the management of this subtask.

The Jet Propulsion Laboratory is responsible for the Applied Nickel-Cadmium Technology subtask. This aubtask involves the development of an electrochemical model of the nickel-cadmium system that involves physical, chemical, and electrochemical studies at the component and cell levels. The model will be used to develop an accelerated test which can be used to determine the quality and reliability of fight lot cells without extensive life testing and to predict the performance of a battery from a set of spacecraft operating conditions. Phase I of the model, which involves using a table lookup approach for determining cell performance, has been implemented and is available for distribution through COSMIC. Phase II of the model involves the replacement of the table lookup approach used in Phase I with a one dimensional electrochemical model being developed under a contract with Texas A\&M. The model, simulating the charge and discharge, is being developed. The model predictions match actual test data through much of the cycle life. The Phase II model is scheduled to be complete in September of 1990 . The third and final phase of the model involves the expansion to a two dimensional model and the incorporation of factors to predict performance degradation. The Phase III model is scheduled to be complete in May of 1992. Additional information on the status of this effort is available in references 5-10.

The major goal of the Nickel-Hydrogen Technology subtask is to define the features of a NASA Standard Nickel-Hydrogen cell. Steps are underway to evaluate the critical aspects of nickel-hydrogen technology in order to prevent a situation similar to that presently being experienced with nickel-cadmium cells and to ensure the consistent production of quality cells. The Lewis Research Center has responsibility for the NickelHydrogen Technology oubtask. It involves coordination of Code $R_{1}$ Office of Aeronautics, Exploration and Technology, efforts and Code $Q$ support for the verification and qualification of technology advances identified through the Code $R$ program. Currently, the effects of the NASA advanced design features and the effects of $26 \%$ va $31 \% \mathrm{KOH}$ are being evaluated in fight cells being tested at Crane. Preliminary results of the testing of cells with varied KOH concentration support the accelerated boiler plate tests run previously Two of the three cells containing $31 \% \mathrm{KOH}$ failed before cycle 4500 , the three cells with $26 \% \mathrm{KOH}$ and the remaining cell with $31 \%$ KOH have accumulated $>9000,80 \%$ DOD LEO cycles and continue on test. The testing of the advanced design features is apecifically evaluating the effect of the catalyzed-wall wick on cell life and performance. Following 5300, 60\% DOD LEO cycles, the cells with the catalyst on the wall have a $46 \mathrm{mv}$ higher end-of-discharge voltage than those without the catalyst. Details on the status of these evaluations can be found in references 11 and 12 . Flight cells are also being built which will evaluate potential replacements for the asbestos separators presently used in nickel-hydrogen cells. FY90 funding is being used to support cycle testing of the above groups of cells and to perform destructive physical analyses as the cells fail. The effects of impregnation method and cell design on performance and cycle life are also being investigated. This subtask involves close coordination with Hubble Space Telescope and Space Station Freedom, missions which are using or will use nickel-hydrogen batteries for energy storage.

A subtask which involves the implementation of a program of independent checks and balances was added to the Secondary Battery Technology Task in response to the current nickel-cadmium situation. The increased checks and balances are aimed at identifying potential problem areas in a timely manner so that appropriate actions can be taken to correct the problems with minimal impact. The independent checks and balances include the following: 1) test facility upgrades; 2) support of task force activities to investigate specific areas as they arise; 3) the establishment of an independent DPA facility to perform routine diagnostic component testing; 4) the investigation of impedance as an interpretative tool for determining cell quality; and 5) the development of NDE methods for nickel-hydrogen cell cases.

The expansion and upgrading of test facilities at JPL and Goddard, planned as part of the independent checks and balances effort, will provide increased capability within NASA for the non-routine testing and mission simulation of cells and batteries for future NASA missions. JPL has built five test stands capable of performing parametric characterization and mission simulation type testing. Five additional stands are scheduled to be completed with FY90 funding. Goddard facilities will be updated in future years as funding allows.

Several of the task force activities initiated at the Nickel-Cadmium Mini-Workshop held at the NASA Marshall Space Flight Center (MSFC) in June of 1988 are continuing as a part of the increased checks and balances effort. These include the Crane Data Evaluation effort, the Quality Oversight Task, the effort for the Establishment of Standard DPA Procedures, and the Separator Test Procedures Task.

The Crane Data Evaluation task force determined that the present data base of Crane data is not useful for the determination of product consistency or otatistical relationships. The task force role has been expanded to include the identification of a meaningful test matrix for the testing and evaluation of cells for LEO and GEO applications. JPL has responsibility of organizing this activity. A contract has been let with MRJ to perform this work. A report will be issued summarizing the results of the investigation.

As part of the Quality Oversight Task, the GSFC Flight Assurance Office has developed NASA Performance Assurance Requirements (PAR) for Flight Ni-Cd Cells. This document will be incorporated into the revision to NHB 8073.1 , NASA Specification for Manufacturing and Performance Requirements of NASA 
Standard Aerospace Nickel-Cadmium Cells.

The Marshall Space Flight Center has assumed the responsibility for developing and establishing NASA standards for the performance of destructive physical analyses. A draft DPA procedure has been circulated for review. An approved version of the procedure will become the NASA Standard DPA Procedure and be implemented at the independent DPA facility that is being established as part of this subtask. Here the objective is to establish an independent facility for the performance of DPA's and routine diagnostic tests for cecondary cells. The Marshall Space Flight Center is organizing efforts relating to the establishment of the independent DPA facility.

A task force group was formed to evaluate the present -eparator test procedures used to screen and evaluate -eparator uniformity and quality for use in nickelcadmium cells. The Lewis Research Center is involved in defining improved tests that will more closely evaluate separator characteristics as related to the actual cell environment. '

As part of an effort to understand and define the component properties that lead to reliable, high performance cells JPL is performing a task that involves comparing properties of plates produced in the 1970's when cells were relatively problem free to those of plates made more recently. References 13 and 14 summarize the work performed to date under this subtask.

Efforts are underway to investigate the use of impedance spectroscopy as an interpretive tool for predicting cell performance and quality. The Lewis Research Center is responsible for this effort. The status of the efforts in this have been reported in references $15-20$.

The mechanical aspects of nickel-hydrogen case integrity and non-destructive evaluation of the cell closure welds are of particular concern for determining flight worthiness of nickel-hydrogen cells. As a part of this program the Lewis Research Center is responsible for investigating advanced NDE techniques for flaw definition and flaw growth in nickel-hydrogen cell cases. This subtask involves close coordination with efforts being conducted by the Space Station Freedom Program Office.

\section{Primary Battery Technology}

The objective of the Primary Battery Technology Task is to improve the performance, reliability and safety of primary battery aystems. The major thrust of this effort is to reduce the number of different cell chemistries now used by identifying and qualifying high performance NASA Standard Primary Cells. The Johnson Space Center has primary responsibility for work performed under this task.

A Primary Battery Design and Safety Handbook has been prepared and is expected to be published in the near future. It is intended that the handbook provide National Space Transportation System users with the necesary guidelines, standard testing procedures and requiremente to enaure mission success.

An excess of a dozen different cell chemiatries are presently used by NASA to provide the power requirements for primary battery applications. Many of the cells and batteries used are commercially available off-the-shelf items. As a result, NASA has no control over the manufacturing processes used to produce these cells. Therefore, NASA, through JSC, is in the process of setting up a logistics source of primary cells that will have been previously screened and qualified. This will help to ensure the cell/battery quality and result in greater system reliability.

Studies have been conducted in order to minimize the number of cell chemistries which would represent an overall optimum for all NASA missions. The high rate $\mathrm{Li}-\mathrm{SOCl}_{3} \mathrm{D}-\mathrm{Cell}$, the $\mathrm{Li}-\mathrm{BCX}$, and the $\mathrm{Zn}-\mathrm{O}_{2}$ systems will be evaluated via testing. Subtasks are underway which are designed to optimize these systems and make them safer for use.

A lithium cell shorting hazards definition task is being conducted to determine the maximum heat generation during horting for a variety of lithium cell presently in use by flight programs. The results of this subtask will aid in the investigation of internal/external short circuit protection for lithium cells. The objective of this subtask is to develop a positive control for both internal and external short circuits in lithium cells. The control is activated by temperature, shutting the cells down from the heat generated by shorts.

A performance/abuse/cycle life evaluation of newly developed $\mathrm{Li}-\mathrm{SOCl}_{2} \mathrm{D}$ cells is being conducted to aid in the qualification of the high rate cell developed by JPL.[21] Parametric performance and abuse tests and cycle life tests will be run.

The NASA Aerospace Flight Battery Systems Program also supports the development of a pair of $\mathrm{Zn}-\mathrm{O}_{2}$ cells: a high capacity cell of $150-200 \mathrm{AH}$ at rates of $25-100$ hours and smaller capacity 9-12 AH cell to be operated at higher rates of 3-12 hours.

\section{CONCLUDING REMARKS}

The NASA Aerospace Flight Battery Systems Program provides for a balanced cell, battery and systems program which includes primary and secondary battery activities in support of NASA's llight programs. It has provided for increased communication within the agency and within the battery industry as well. The program addresses flight battery and related flight power system activities which are essential for ensuring safe and reliable performance. The secondary nickel-cadmium cells are the top priority of the program. In addition, continuing efforta in the nickel-hydrogen and primary battery areas are aimed at preventing the recurrence of the similar problems in these areas.

\section{REFERENCES}

[1] N.R. Schulze, "NASA Aerospace Battery Syatem Program Initiation", 22nd IECEC Conference, 1987, pp 48-50.

2] O.D. Gonzalez-Sanabria, "NASA Aeronpace Flight Battery Systern Program Plan", Journal of Power Sources, Vol 21, Oct/Nov 1987, pp 177-179. 
[3] N.R. Schulze, and O.D. Gonzalez-Sanabria, "NASA Aerospace Battery Systems Program - Issues and Actions", 23rd IECEC Conference, 1988, Vol 2, pp 35.

4) M.A. Manzo, and N.R. Schulze, "NASA Aerospace Battery Systems Program Update", 24th IECEC Conference, 1989, Vol, pp 1401-1404.

[5] K. Clark, G. Halpert, and P. Timmerman, "NickelCadmium Battery Performance Simulation: A Means Toward Optimum Design in Satellite Applications", 23rd IECEC Conference, Denver, Colorado, August 1988.

|6] K. Clark, G. Halpert, and P. Timmerman, "NickelCadmium Battery Performance Modelling", 24th IECEC Conference, Washington, D.C., August 1989.

7) P.R. Gluck and P.J. Timmerman, "Modelling a Nickel-Cadmium Battery as a Heterogeneous Device", 5 th Annual Long Beach Conference on Applications and Advances, Long Beach, CA, January 1990.

[8] D. Fan and R. White, "A Mathematical Model of a Sealed Nickel-Cadmium Battery", 5th Annual Long Beach Conference on Applications and Advances, Long Beach, CA, January 1990.

9) P.R. Gluck and P.J. Timmerman, "Modelling a Nickel-Cadmium Battery as a Heterogeneous Device", 25th IECEC Conference, Reno, NV, August 1990.

(10) P.J. Timmerman, D. Fan, and R. White, "NickelCadmium Battery Cell Performance Predictions Using a Macrohomogeneous Computer Model", 25th IECEC Conference, Reno, NV, August 1990.

(11) J. Smithrick and S. Hall, "Effect of $\mathrm{KOH}$ Concentration on LEO Cycle Life on IPV NickelHydrogen Battery Cells", 25th IECEC Conference, Reno, NV, August 1990.

(12) J. Smithrick and S. Hall, "Effect of LEO Cycling on 125 AH Advanced Design IPV Nickel-Hydrogen Battery Cells", 25th IECEC Conference, Reno, NV, August 1990.

[13] S. DiStefano, P.J. Timmerman and G. Halpert, "Electrochemical Evaluation of Nickel-Cadmium Plate Materials", 5th Annual Long Beach Conference on Applications and Advances, Long Beach, CA, January 1990.

14) S. DiStefano, P.J. Timmerman and G. Halpert, Evaluation of Fundamental Electrochemical Parameters of Nickel-Cadmium Plate Material", 25th IECEC Conference, Reno, NV, August 1990.

(15) M.A. Reid, "Impedances of Nickel Hydroxide Electrodes as Functions of Potential and Electrode Type," Extended Abstracts of the 174th Electrochemical Society Meeting, Chicago, IL, Oct. 1988, p. 122.

16) M.A. Reid, "Impedance Studies of Ni/Cd and $\mathrm{Ni} / \mathrm{H}_{3}$ Cells Using the Cell Case as a Reference Electrode", Proceedings of the 2nd SERT Conference, NASA Lewis Research Center, Cleveland, OH, April 11. 13,1989, p. 197 and J. Power Sources, to be published.

17] M.A. Reid, "Impedances of Electrochemically Impregnated Nickel Electrodes as Functions of Potential, $\mathrm{KOH}$ Concentration and Impregnation Method",
Electrochim. Acta, in press and NASA TM, in press.

18) M.A. Reid, "Changes in Impedance of $\mathrm{Ni}$ Electrodes upon Standing and Cycling", Nickel Hydroxide Electrodes (D.A. Corrigan and A.H. Zimmerman, Eds.), Proceedings Vol. 90-4, The Electrochemical Society, Pennington, NJ, 1990, pp. 296310 and Extended Abstracts of the 176th Electrochemical Socjety Meeting, Hollywood, FL, 1990.

19) M.A. Reid, "Impedances of Ni Electrodes and $\mathrm{Ni} \mathrm{H}_{2}$ Cells from Different Manufacturers," Proceedings of the 25th IECEC Conference, Reno, NV, 1990.

(20) M.A. Reid and P.L. Loyselle, "Modeling of Impedance of Nickel Electrodes Using a More Detailed Electrical Circuit", Extended Abstracts of the 178th Electrochemical Society Meeting, Seattle, WA, Oct. 1990 , in press.

21] F. Deligannis and S.J. Ebel, Influence of Cell Design on Performance of $\mathrm{Li}-\mathrm{SOCl}_{2}$ ' $D$ ' Size Cells", 5th Annual Long Beach Conference on Applications and Advances, Long Beach, CA, January 1990. 


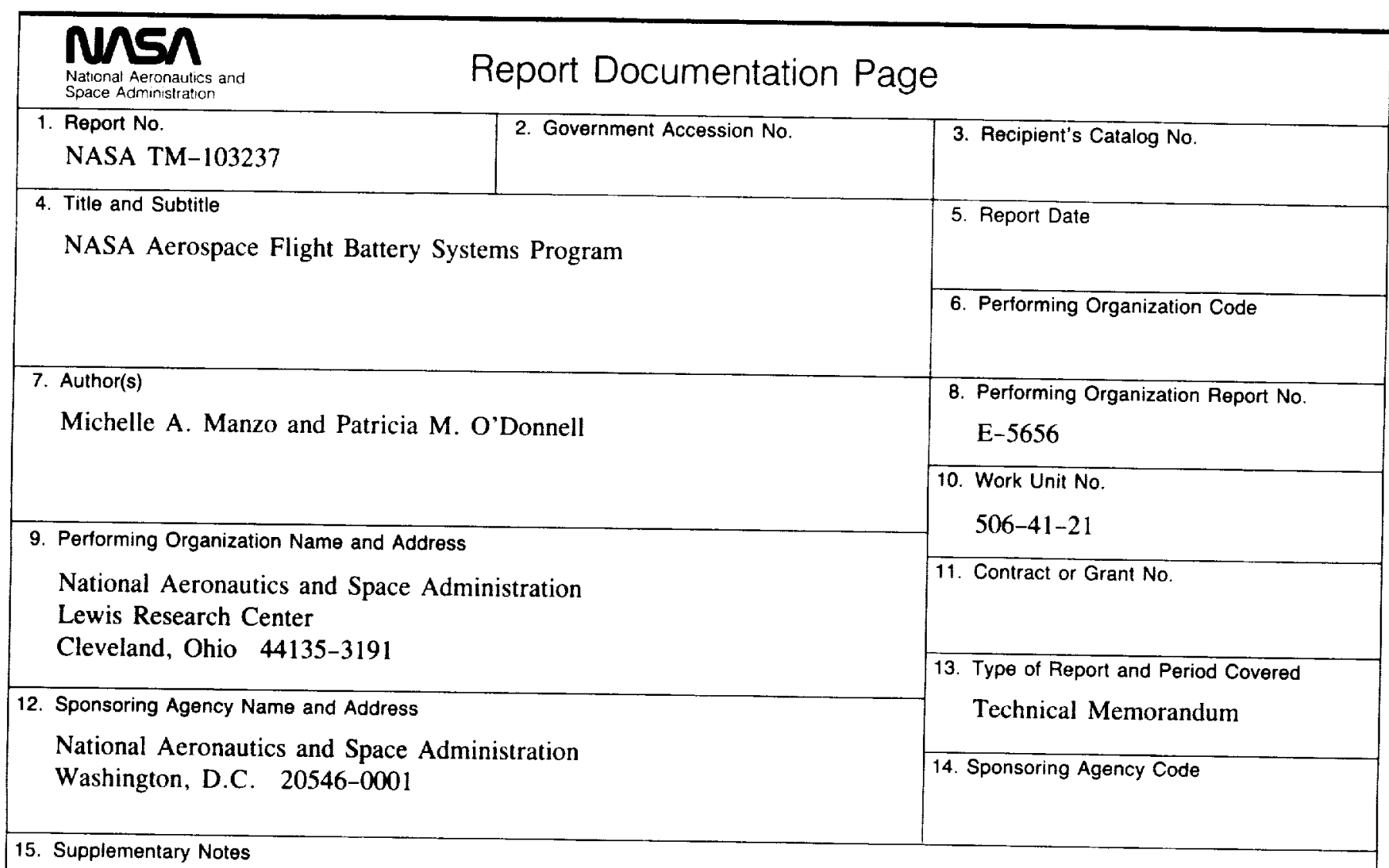

Prepared for the 25th Intersociety Energy Conversion Engineering Conference cosponsored by the AIChE, ANS, SAE, ACS, AIAA, ASME, and IEEE, Reno, Nevada, August 12-17, 1990.

16. Abstract

The major objective of the NASA Aerospace Flight Battery Systems Program is to provide NASA with the policy and posture to increase and ensure the safety, performance and reliability of batteries for space power systems. The program plan has been modified in the past year to reflect changes in the agency's approach to battery related problems that are affecting flight programs. Primary attention in the Battery Program is being devoted to the development of an advanced nickel-cadmium cell design and the qualification of vendors to produce cells for flight programs. As part of a unified Battery Program, the development of a nickel-hydrogen standard and primary cell issues are also being pursued to provide high performance NASA Standards and space qualified state-of-the-art primary cells. The resolution of issues is being addressed with the full participation of the aerospace battery community.

17. Key Words (Suggested by Author(s))

Aerospace batteries

Ni-Dd batteries

$\mathrm{Ni}-\mathrm{H}_{2}$ batteries

Lithium batteries
18. Distribution Statement

Unclassified - Unlimited

Subject Category 44
19. Security Classif. (of this report) Unclassified
20. Security Classif. (of this page) Unclassified
21. No. of pages 6
22. Price*

$\mathrm{A02}$ 